\title{
PERANAN MEWARNAI MANDALA DALAM MENURUNKAN KECEMASAN MENGERJAKAN SKRIPSI PADA MAHASISWA FAKULTAS PSIKOLOGI UNIVERSITAS NEGERI MAKASSAR
}

\author{
Indah Luthfiyah Kasim*, Widyastuti, dan Ahmad Ridfah \\ Fakultas Psikologi, Universitas Negeri Makassar \\ Jl. A. P. Pettarani, Tidung, Kec.Rappocini, Kota Makassar, Sulawesi Selatan \\ E-mail: indahluthfiyahkasim@gmail.com
}

\begin{abstract}
ABSTRAK
Mahasiswa yang mengalami kecemasan mengerjakan skripsi merasa tidak mampu mengerjakan skripsi, khawatir tidak menguasai tema penelitian, perasaan tidak tenang ketika sulit menemukan literatur. Mahasiswa yang tidak mampu mengatasi kecemasan akan memilih untuk menunda hingga meninggalkan pengerjaan skripsi. Kecemasan mengerjakan skripsi mahasiswa tergolong tinggi, sehingga dibutuhkan suatu metode untuk menangani kecemasan. Salah satu metode penanganan kecemasan adalah dengan mewarnai mandala. Pola mandala yang terstruktur dapat memberi efek meditasi yang menenangkan. Penelitian ini bertujuan untuk mengetahui peranan metode mewarnai mandala dalam menurunkan kecemasan pada mahasiswa Fakultas Psikologi di Universitas Negeri Makassar yang sedang mengerjakan skripsi. Penelitian ini menggunakan metode quasi-eksperimental dengan desain pretest-posttest one group with follow up. Mewarnai mandala dilaksanakan selama empat hari (masing-masing 45 menit). Partisipan berjumlah delapan orang yaitu mahasiswa yang memiliki skor pretest berkategori tinggi dan sangat tinggi. Instrumen yang digunakan adalah skala $\left(\mathrm{r}_{\mathrm{xy}}=0,5549-0,909\right)$, koefisien alpha $\left.=0,924\right)$ yang disusun oleh Lovibond \& Lovibond (1995). Uji Wilcoxon menunjukkan bahwa pada saat pretest vs. posttest $(\mathrm{MD}=50,37)$, pretest vs. follow up $(\mathrm{MD}=$ 24,745), posttest vs. Follow up $(\mathrm{MD}=17,81)$. Uji Friedman menunjukkan skor $\mathrm{p}=0,001$, sehingga terdapat perbedaan skor kecemasan yang signifikan. Implikasi dari penelitian ini adalah pemberian metode mewarnai mandala yang dilakukan dapat menurunkan kecemasan mengerjakan skripsi yang dialami mahasiswa FPSI UNM.
\end{abstract}

Kata kunci: mahasiswa; kecemasan; mewarnai mandala; eksperimen kuasi

Judul bhs inggris blm lagi ditanyain

ABSTRACT

Students who experienced anxiety felt like they are unable to work on their thesis, worried that they will not be able to comprehend the research theme, felt uneasy when encountering difficulties in finding pieces of literature. Students that are unable to cope with anxiety will choose to postpone and even leave it as it is. The anxiety of doing student thesis is high. Therefore, we need a method to deal with the condition. One method of dealing with anxiety is by colouring mandalas. A structured mandala pattern can have a soothing, meditative effect. This study aims to determine the role of the mandala colouring method in reducing anxiety among students of the Faculty of Psychology in Makassar State University who are currently working on their thesis. This study used a quasi-experimental method with one group pretest-posttest design with follow up. Colouring mandalas was carried out for four days (@ 45 minutes). There were eight participants, namely students who had 'high' and 'very high' pretest scores. The instrument used is the scale $\left(\mathrm{r}_{\mathrm{xy}}=0.5549-0.909\right)$, Alpha coefficient $\left.=0.924\right)$ designed by Lovibond \& Lovibond (1995). Wilcoxon test showed that at the time of the pretest vs. posttest $(\mathrm{MD}=50.37)$, pretest vs. follow up $(\mathrm{MD}=24.745)$, and posttest vs. follow up $(\mathrm{MD}=17.81)$. Friedman test shows a score of $\mathrm{p}=.001$, so there is a significant difference in anxiety scores. This research implies that the mandala colouring method can reduce the anxiety of working on thesis experienced by students.

Keywords: student; anxiety; thesis; coloring mandala; quasi experiment 


\section{PENDAHULUAN}

Kamus Besar Bahasa Indonesia (KBBI) Online menjelaskan bahwa skripsi merupakan karya ilmiah yang wajib disusun sebagai persyaratan akhir dalam pendidikan akademis. Mahasiswa yang mengerjakan skripsi kerap menemui tantangan eksternal seperti sulit bertemu dosen pembimbing, proses birokrasi yang panjang dan khawatir ketika mendengar judul tidak diterima (Asmawan, 2016). Tekanan dari dalam dan luar diri seperti tuntutan untuk menyelesaikan skripsi tepat waktu akan memicu timbul kecemasan pada mahasiswa jika tidak mampu mengatasi tekanan dari dalam dan luar diri (Amaliyah \& Palia, 2015). Kecemasan mengerjakan skripsi merupakan reaksi emosi individu karena tidak mampu mengatasi berbagai rintangan dalam proses pengerjaan skripsi Fikry \& Khairani (2017).

Mahasiswa yang mengalami kecemasan akan merasa takut dievaluasi, sulit menuangkan ide, memikirkan akan memperoleh nilai yang buruk,merasa memiliki kemampuan menulis yang buruk, dan merasa tidak mampu menyelesaikan skripsi (Deasyanti \& Nuruzdah (2017). Lovibond dan Lovibond (1995) mengemukakan bahwa aspek kecemasan terbagi dalam empat kelompok respon, yaitu rangsangan saraf otonom, respon otot rangka, kecemasan situasional, dan perasaan cemas yang subjektif. Kecemasan memiliki empat tingkatan, yaitu ringan, sedang, berat, dan panic (Videbeck, 2011)

Situmorang (2018) mengemukakan bahwa jika masalah dalam proses pengerjaan skripsi terus dibiarkan dapat memunculkan gejala negatif pada aspek fisik maupun psikis yang dapat menghambat proses penyelesaian studi. Mahasiswa akan mengalami penurunan kemampuan menghubungkan antara persoalan, perhatian, daya ingat, hingga distorsi persepsi sebagai akibat dari kecemasan (Listanto \& Demak, 2015). Kecemasan dalam mengerjakan skripsi memunculkan masalah yang berhubungan dengan psikologis seperti seperti sulit berkonsentrasi dan gemetar ketika melakukan konsultasi Situmorang (2017). Individu akan kebingungan untuk menentukan sikap atau perilaku yang positif jika kecemasan tidak diatasi (Harini, 2013).

Kecemasan mengerjakan skripsi dapat diturunkan dengan berbagai macam metode, salah satu metode yang dapat dilakukan adalah mewarnai, seperti mewarnai mandala, plaid, dan lembar kosong. Curry \& Kasser (2005) mengemukakan bahwa mewarnai pada pola lebih efektif menurunkan kecemasan daripada lembar kosong. Vennet \& Serice (2012) mengemukakan bahwa mewarnai pada pola mandala lebih efektif menurunkan kecemasan daripada plaid.

Pisarik \& Larson (2011) mengemukakan bahwa Jung memandang mandala sebagai desain artistik yang dibuat dalam bentuk lingkaran yang mewakili makna diri. Hal ini juga sesuai dengan hasil peneltian Henderson, Rosen, \& Mascaro (2007) yang menunjukkan bahwa struktur desain melingkar yang terdiri dari bentuk simetris yang secara teratur dari mandala dapat digunakan untuk tujuan meditasi. Mewarnai mandala adalah aktivitas memberi warna tertentu pada pola khas berbentuk garis dan lingkaran yaitu pola geometri (Harms, 2011)

Warna memiliki peran penting dalam memberikan pengaruh tertentu dan sebagai penghidup jiwa. mengemukakan bahwa warna dapat merangsang, membangkitkan, menekan, menenangkan, dan menciptakan perasaan hangat atau dingin. Metode pewarnaan menjadi lebih efektif ketika disandingkan dengan media terstruktur (Babin, 2013). Ide dasar dari terapi pewarnaan terletak pada emosi. Individu yang melakukan aktivitas mewarnai diatas media berbentuk geometris yang kompleks, secara tidak langsung akan melibatkan perasaan batin yang mendalam (Curry \& Kasser, 2005). Lebih lanjut Fincher (2000) menjelaskan bahwa warna dalam mandala memiliki makna. Warna hijau memberi kesan kesegaran,jingga memberi kesan keseimbangan dan daya tahan, ungu memberi kesan kesabaran, merah memberi energi, biru memberi kesan menenangkan, dan kuning memberi kesan kesadaran yang tinggi.

Curry \& Kasser (2005) melakukan penelitian pada 84 (55 perempuan) mahasiswa sarjana perguruan tinggi seni di Midwestern. Partisipan diberi intervensi berupa mewarnai pada pola mandala, plaid, dan kertas kosong selama dua puluh menit. Hasil penelitian menunjukkan penurunan kecemasan peserta yang mewarnai pada pola terstruktur seperti mandala, namun tidak pada peserta yang diminta mewarnai pola tidak terstruktur di atas lembar kosong.

Vennet \& Serice (2012) melakukan penelitian replikasi dari Curry \& Kasser (2005) kepada 50 (41 wanita) mahasiswa psikologi di Universitas AS dengan membagi partisipan kedalam dua kelompok selama dua hari. Hasil penelitian menunjukkan bahwa mewarnai mandala efektif dalam mengurangi kecemasan secara signifikan lebih besar daripada mewarnai pada desain plaid dan mewarnai pada kertas kosong. 
Anderson (2017) mengemukakan bahwa individu dapat mengekspresikan diri secara simbolis dan menemukan ketenangan pikiran melalui aktivitas mewarnai mandala. Mandala berfungsi sebagai representasi simbolis dari emosi dan konflik, namun secara bersamaan dapat memberikan rasa keteraturan dan integrasi. Aktivitas mewarnai pada seluk-beluk bentuk simetris dalam lingkaran mandala yang terstruktur dapat memberikan efek meditasi yang menenangkan (Carsley, Heath, \& Fajnerova, 2015).

Penelitian ini adalah untuk mengetahui peranan metode mewarnai mandala dalam menurunkan kecemasan pada mahasiswa FPSI UNM yang sedang mengerjakan skripsi. Hipotesis penelitian ini adalah metode mewarnai mandala berperan dalam menurunkan kecemasan pada mahasiswa FPSI UNM yang sedang mengerjakan skripsi.

\section{METODE PENELITIAN}

Penelitian ini merupakan penelitian kuasi eksperimental dengan one-group pretest-posttest design with follow up yang merupakan desain penelitian dengan melakukan pengukuran variabel terikat pada partisipan. Pengukuran variabel terikat kembali diberikan kepada partisipan setelah perlakuan (Seniati, Yulianto, \& Setiadi, 2011).

Pretest dilakukan untuk mengetahui tingkat kecemasan partisipan dengan memberikan skala kecemasan dalam mengerjakan skripsi. Pretest $\left(\mathrm{O}_{1}\right)$ diberikan satu hari sebelum pemberian perlakuan.Perlakuan dalam penelitian ini berupa mewarnai mandala selama 45 menit dengan menggunakan enam pensil warna (merah, kuning, ungu, biru, hijau dan jingga), rautan, dan kertas yang berisi pola mandala. Selama empat hari pemberian intervensi diberikan pola yang berbeda. Posttest $\left(\mathrm{O}_{2}\right)$ diberikan sesaat setelah pemberian perlakuan pada hari terakhir dengan menggunakan skala DASS-A. Follow up $\left(\mathrm{O}_{3}\right)$ dilakukan untuk mengukur tingkat kecemasan mengerjakan skripsi tujuh hari setelah pemberian posttest.

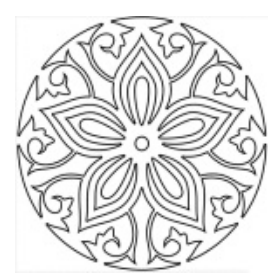

Coloringpages 101.com

Hari 1

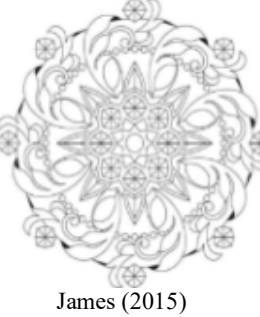

Hari 2

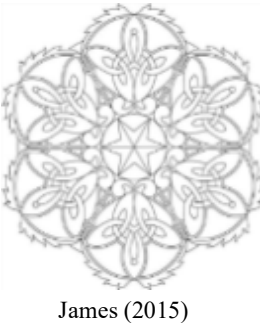

Hari 3

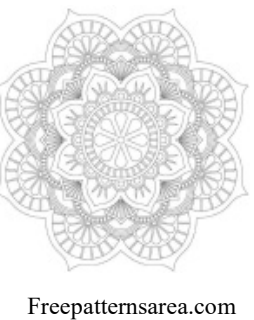

Hari 4

Gambar 1. Pola Mandala

Pola mandala yang digunakan adalah yang mendekati model pola mandala yang digunakan oleh Curry \& Kasser (2005) yaitu berbentuk melingkar, memilikidesain geometris yang kompleks, dan memiliki pusat pada bagian tengah pola. Pada penelitian Pada penelitian ini, digunakan empat macam pola mandala karena pemberian intervensi dilakukan sebanyak empat kali. Pemilihan urutan empat pola mandala ditetapkan berdasakan hasil uji coba kepada mahasiswa untuk memberi pendapat dengan cara mengurutkan dari yang memiliki kompleksitas rendah hingga tinggi.

Partisipan melakukan aktivitas mewarnai mandala menggunakan pensil warna yang terdiri dari warna merah, kuning, ungu, biru, hijau dan jingga diatas lembar kertas yang memiliki pola mandala.Pemilihan warna ini didasarkan pada penelitian sebelumnya yang dilakukan oleh Curry \& Kasser (2005).

Karakteristk partisipan dalam penelitian ini yang pertama merupakan mahasiswa FPSI UNM yang sedang mengerjakan skripsi. Kedua,memiliki tingkat kecemasan mengerjakan skripsi kategori tinggi berdasarkan skor pretest. Ketiga, bersedia mengikuti serangkaian penelitian dari awal hingga akhir.Teknik pengambilan sampel yang digunakan dalam penelitian ini adalah purposive sampling sehingga diperoleh delapan mahasiswa yangmewakili semua populasi. 
Penelitian dilaksanakan berdasarkan panduan penelitian yang telah dibuat. Peneliti membuka kegiatan dengan perkenalan, penjelasan singkat mengenai mewarnai mandala, dan mempersilahkan partisipan mengisi surat kesediaan, kemudian memberi intruksi pengerjaan tugas berdasarkan panduan penelitian. Partisipan melakukan tugas mewarnai mandala selama 45 menit menggunakan enam pensil warna selama empat hari. Setiap partisipan menggunakan alat mewarnai berupa pensil warna dan pola yang sama. Setelah menyelesaikan tugas, partisipan mengisi lembar kesan-kesan mengenai apa yang dirasakan sebelum dan setelah mewarnai mandala. Pada desain ini partisipan diberi pretest sebelum perlakuan dan diukur kembali setelah perlakuan, sehingga hasil perlakuan dapat ditekahui lebih akurat karena dapat membandingkan dengan keadaan sebelum perlakuan.

Teknik pengumpulan data dalam penelitian ini adalah dengan menggunakan skala, lembar observasi, dan lembar kesan-kesan. Instrumen utama dalam penelitian ini adalah adaptasi skala Depression Anxiety Stress Scales (DASS-A) yang disusun oleh Lovibond \& Lovibond (1995). Hasil validitas pada setiap aspek menunjukkan satu aitem yang memiliki standardized loading factor dengan nilai dibawah 0,5 sehingga terdapat satu aitem yang gugur dan seluruh aspek dinyatakan valid $\left(\mathrm{r}_{\mathrm{xy}}=0,5549-0,909\right)$ dengan koefisien alpha sebesar 0,924 yang menunjukkan tingkat reliabilitas skala tergolong bagus (Azwar, 2016). Lembar observasi dankesan-kesan digunakan untuk mendukung hasil dari pengukuran DASS-A. Analisis validitas DASS-A diperoleh dengan menggunakan confirmatory factor analysis (CFA) dengan bantuan aplikasi STATCAL.

Analisis data penelitian ini dilakukan menggunakan analisis statistik uji Friedman dan uji Wilcoxon dengan bantuan aplikasi bantuan IBM SPSS Statistics 22. Uji Friedman dilakukan untuk melihat peranan mewarnai mandala secara umum untuk seluruh partisipan. Uji Wilcoxon terhadap skor pretest, posttest, dan follow up dilakukan guna mengetahuipengaruh mewarnai mandala terhadap kecemasan mengerjakan skripsi pada tiap partisipan peneliltian dilihat dari masing-masing pengukuran.

\section{HASIL DAN PEMBAHASAN}

Pada tabel 1 menunjukkan tingkat kecemasan mengerjakan skripsi kelompok eksperimen sebelum diberi perlakuan, dimulai dari kategori sangat tinggi dan tinggi. Partisipan yang terkategori sangat tinggi sebanyak 1 partisipan (10\%) dan terkategori tinggi sebanyak 9 partisipan $(90 \%)$. Tingkat kecemasan mengerjakan skripsi setelah diberi perlakuan dimulai dari kategori rendah hingga tinggi, yaitu 2 partisipan $(20 \%)$ terkategori rendah, 6 partisipan $(60 \%)$ terkategori sedang, dan $2(20 \%)$ terkategori tinggi. Akan tetapi sebanyak dua partisipan tidak mengikuti tahap follow up yaitu pengukuran ke dua.

Tabel 1. Hasil Skor Nilai Pretest dan Posttest Kelompok Eksperimen

\begin{tabular}{lcccccc}
\hline Partisipan & Pretest & Keterangan & Posttest & Keterangan & Follow up & Keterangan \\
\hline P1 & 40 & ST & 19 & S & 19 & S \\
P2 & 34 & T & 12 & R & 10 & R \\
P3 & 34 & T & 27 & T & 26 & T \\
P4 & 33 & T & 20 & S & 18 & S \\
P5 & 31 & T & 17 & S & 17 & S \\
P6 & 30 & T & 15 & S & 19 & S \\
P7 & 28 & T & 21 & S & 15 & S \\
P8 & 27 & T & 15 & S & 15 & S \\
P9 & 34 & T & 28 & T & - & - \\
P10 & 31 & T & 11 & R & - & - \\
\hline
\end{tabular}

ST: Sangat tinggi, T: Tinggi, S: Sedang, R: Rendah

Keterangan -: Tidak mengikuti kegiatan

Hipotesis penelitian ini adalah metode mewarnai mandala berperan dalam menurunkan kecemasan pada mahasiswa FPSI UNM yang sedang mengerjakan skripsi.Uji hipotesis digunakan untuk mengetahui perbedaan secara umum yang diuji dengan teknik uji non-parametrik menggunakan uji Friedman dengan bantuan program IBM SPSS Statistics 22.0. Hasil menunjukkan nilai signifikansi sebesar $p=0,001$ yang berarti $\mathrm{H}_{0}$ ditolak dan $\mathrm{H}_{\mathrm{a}}$ diterima. Maka mewarnai mandala efektif untuk menurunkan kecemasan mengerjakan skripsi mahasiswa FPSI UNM yang sedang mengerjakan skripsi. 
Peneliti melakukan uji Wilcoxon terhadap skor pretest, posttest, dan followup guna mengetahui adanya pengaruh mewarnai mandala terhadap kecemasan mengerjakan skripsi pada tiap partisipan penelitian. Pertama perbandingan antara pengukuran pertama yaitu pretest $\left(\mathrm{O}_{1}\right)$ dan pengukuran kedua yaitu posttest $\left(\mathrm{O}_{2}\right)$. Pengukuran ini dilakukan dengan menggunakan uji Wilcoxon signed ranks test dengan bantuan IBM SPSS Statistics 22.

Tabel 2. Hasil Uji Perbandingan Pengukuran $\mathrm{O}_{1}$ dan $\mathrm{O}_{2}$

\begin{tabular}{lccc}
\hline Pengukuran & $\mathbf{M}$ & $\mathbf{p}$ & Keterangan \\
\hline $\mathrm{O}_{1}$ & 32,12 & 0,012 & Signifikan \\
\hline $\mathrm{O}_{2}$ & 18,25 & & \\
\hline
\end{tabular}

M: nilai rata-rata, p: nilai signifikansi

Tabel diatas menunjukkan nilai signifikansi sebesar $\mathrm{p}=0,012$, sehingga $\mathrm{H}_{0}$ ditolak dan $\mathrm{H}_{\mathrm{a}}$ diterima. Maka terdapat perbedaan skor kecemasan sebelum dan setelah mengikuti aktivitas mewarnai mandala. Nilai signifikansi menunjukkan bahwa skor kecemasan mengerjakan skripsi partisipan pada pengukuran pertama lebih tinggi daripada pengukuran kedua.

Hasil uji perbandingan pengukuran pretest dan follow up nilai signifikansi sebesar $\mathrm{p}=0,012$, yang berarti $\mathrm{H}_{0}$ ditolak dan $\mathrm{H}_{\mathrm{a}}$ diterima. Maka terdapat perbedaan skor kecemasan sebelum dan satu pekan setelah mengikuti aktivitas mewarnai mandala. Nilai signifikansi menunjukkan bahwa skor kecemasan mengerjakan skripsi partisipan pada pengukuran pertama lebih tinggi daripada pengukuran ketiga.

Tabel 3. Hasil Uji Perbandingan Pengukuran $\mathrm{O}_{1}$ dan $\mathrm{O}_{3}$

\begin{tabular}{llcc}
\hline Pengukuran & $\mathbf{M}$ & $\mathbf{p}$ & Keterangan \\
\hline $\mathrm{O}_{1}$ & 32,12 & 0,012 & Signifikan \\
\cline { 1 - 2 } $\mathrm{O}_{3}$ & 17,37 & & \\
\hline M: nilai rata-rata, p: nilai signifikansi &
\end{tabular}

Hasil uji perbandingan pengukuran posttest dan follow up menunjukkan nilai signifikansi sebesar $\mathrm{p}=0,343$, yang berarti $\mathrm{H}_{0}$ diterima dan $\mathrm{H}_{\mathrm{a}}$ ditolak. Maka tidak terdapat perbedaan skor kecemasan satu pekan setelah mengikuti aktivitas mewarnai mandala. Nilai signifikansi menunjukkan bahwa skor kecemasan mengerjakan skripsi partisipan pada pengukuran kedua tidak lebih tinggi daripada pengukuran ketiga.

Tabel 4. Hasil Uji Perbandingan Pengukuran $\mathrm{O}_{2}$ dan $\mathrm{O}_{3}$

\begin{tabular}{|c|c|c|c|}
\hline Pengukuran & $\mathbf{M}$ & $\mathbf{p}$ & Keterangan \\
\hline $\mathrm{O}_{2}$ & 18,25 & \multirow{2}{*}{0,343} & \multirow{2}{*}{ Tidak Signifikan } \\
\hline $\mathrm{O}_{3}$ & 17,37 & & \\
\hline
\end{tabular}

M: nilai rata-rata, $\mathrm{p}$ : nilai signifikansi

Hasil menunjukkan bahwa terdapat penurunan skor kecemasan pada setiap waktu pengukuran. Berdasarkan hasil perbedaan mean pada setiap aspek menunjukkan bahwa terdapat perbedaan penurunan pada setiap aspek kecemasan. Dengan demikian dapat disimpulkan bahwa pemberian perlakuan mewarnai mandala efektif menurunkan kecemasan.

Tabel 5. Hasil Perbandingan Mean Setiap Aspek

\begin{tabular}{lccc}
\hline Keterangan & Mean & \multicolumn{1}{c}{ Aspek } & Mean Aspek \\
\hline \multirow{3}{*}{$\mathrm{O}_{1}$} & \multirow{2}{*}{32,12} & Rangsangan saraf otonom & 13,12 \\
\cline { 3 - 4 } & & Respon otot rangka & 5,75 \\
\cline { 3 - 4 } & & Kecemasan situasional & 4,87 \\
\cline { 3 - 4 } & \multirow{3}{*}{18,25} & Perasaan cemas subjektif & 8.37 \\
\cline { 3 - 4 } $\mathrm{O}_{2}$ & & Rangsangan saraf otonom & 7,25 \\
\cline { 3 - 4 } & & Respon otot rangka & 2,75 \\
\cline { 3 - 4 } & 17,37 & Recemasan situasional & 2,75 \\
\hline $\mathrm{O}_{3}$ & & Rangsangan saraf otonom & 7,75 \\
\hline
\end{tabular}




\begin{tabular}{ccc}
\hline & Respon otot rangka & 2.62 \\
\cline { 2 - 3 } & Kecemasan situasional & 3 \\
\cline { 2 - 3 } & Perasaan cemas subjektif & 4,87 \\
\hline
\end{tabular}

Berdasarkan hasil lembar mewarnai mandala pada seluruh partisipan diperoleh yang beragam. Partisipan P1 dan P10 konsisten dengan dominasi warna dalam empat hari penelitian. Partisipan lain menggunakan dominasi warna yang berbeda.

Tabel 6. Dominasi Warna yang Digunakan

\begin{tabular}{lcccc}
\hline Inisial & \multicolumn{4}{c}{ Warna Dominan } \\
\cline { 2 - 5 } (Partisipan) & H1 & H2 & H3 & H4 \\
\hline P1 & Biru & Biru & Biru & Biru \\
P2 & Kuning & Kuning & Ungu & Ungu \\
P3 & Jingga & Jingga & Merah & Merah \\
P4 & Jingga & Biru & Hijau & Kuning \\
P5 & Biru & Kuning & Hijau & Biru \\
P6 & Biru & kuning & Biru & Ungu \\
P7 & Merah & Hijau & Merah & Kuning \\
P8 & Jingga & Jingga & Jingga & Jingga \\
P9 & Hijau & Hijau & Hijau & Hijau \\
P10 & Kuning & Hijau & Biru & Hijau \\
\hline H1:
\end{tabular}

H1: Hari 1, H2: Hari 2, H3: Hari 3, H4: Hari 4

Pada tahapan pretest diperoleh hasil yang menunjukkan mahasiswa memiliki skorkecemasan mengerjakan skripsi pada kategori tinggi dan sangat tinggi. Data menunjukkan bahwa 7 partisipan (87,5\%) terkategori tinggi, 1 partisipan (12,5\%) terkategori sangat tinggi. Fikry \& Khairani (2017) mengemukakan bahwa kecemasan mengerjakan skripsi merupakan reaksi emosi individu karena proses pengerjaan skripsi yang menemukan banyak rintangan.

Berkaitan dengan penelitian yang dilakukan oleh Fikry \& Khairani (2017), diketahui bahwa berdasarkan hasil wawancara, kecemasan mengerjakan skripsi tesebut dikarenakan menemukan banyak rintangan, yaitu rasa takut bertemu dengan dosen pembimbing yang dicirikan dengan gemetar. Mahasiswa merasa tidak tenang, lemas, dan pusing ketika memikirkan hal buruk selama proses pengerjaan skripsi. Mahasiswa khawatir tidak mampu menjawab pertanyaan dari dosen pembimbing dan penguji. Kecemasan mengerjakan skripsi memunculkan berbagai macam masalah psikologi seperti sulit berkonsentrasi dan gemetar ketika melakukan konsultasi Situmorang (2017). Hal ini juga sejalan dengan Deasyanti \& Nuruzdah (2017) yang menjelaskan bahwa mahasiswa yang memiliki kecemasan karena mahasiswa memiliki anggapan skripsi yang dikerjakan akan gagal.

Berdasarkan data skala kecemasan mengerjakan skirpsi diperoleh $87,5 \%$ mahasiswa yang menjadi partisipan memiliki angka kecemasan pada kategori tinggi, 12,5\% terkategori sangat tinggi. Di antara pengalaman fisik dan psikis yang dirasakan adalah aktivitas jantung meningkat saat, bibir kering, gemetar, lemah lunglai, ketakutan, dan kekhawatiran yang subjektif selama proses pengerjaan skripsi.

Pada tahapan pemberian perlakuan dilakukan selama empat hari, perlakuan yang diberikan dalam penelitian ini adalah metode mewarnai mandala. Aktivitas mewarnai mandala dilakukan selama 45 menit dengan pola yang berbeda setiap hari. Setiap partisipan menggunakan jenis pensil warna yang sama. Partisipan duduk pada tempat dan posisi yang tidak berubah. Partisipan diberikan lembar kesan-kesan sebelum dan setelah mewarnai mandala untuk mengetahui secara langsung efek dari aktivitas mewarnai mandala.Kesan yang diberikan partisipan sebelum mewarnai mandala adalah merasa tidak tenang, pusing karena proses penyelesaian skripsi, khawatir dan banyak pikiran mengenai tugas akhir. Berikut kesan yang diberikan partisipan:

"sebelum menggambar masih ada rasa negatif masih tertekan dengan problem dirumah, skripsi, orangtua, dll" 
Peranan Mewarnai Mandala dalam Menurunkan Kecemasan Mengerjakan Skripsi pada Mahasiswa Fakultas Psikologi

Universitas Negeri Makassar

"rasanya banyak pikiran apalagi satu teman sudah S.Psi, ditambah banyak sekali yang tanya tentang perkembangan skripsiku, argh, pusing, cemas. Tapi susah juga mau kerjakan karena nda tau, mager saja, padahal banyakmi teman-teman yang S.Psi."

"saya merasa berat memikirkan beberapa hal dan bingung bagaimana cara untuk menyelesaiannya dan ada sedikit jengkel terhadap sesuatu hal"

"...sempat merasa pusing akibat tugas yang saya kerjakan di perpustakaan tadi"

"saya datang dengan banyak pikiran dikepala, ada rasa khawatir..."

Kesan partisipan setelah mewarnai mandala adalah merasa lebih tenang, bahagia, dan kesadaran diri yang meningkat. Berikut kesan yang diberikan partisipan:

"setelah mewarnai terasa lebih ringan, rileks dan fokus. Saya mengingat jika dulu saya orang yang fokus dan tekun. Sekarang senang dan bahagia karena mengingat bahwa saya dulu orang yang positif, sekarang saya lebih siap untuk melakukan yang terbaik."

"saya merasa senang mewarnainya, setelah selesai saya merasa lega. Penatku sepertinya ikut pergi setelah mewarnai, menjadi lega.”

"saya merasa seperti plong/lega, dan saat mewarnai mandala saya merasa berbicara sendiri dengan diri saya dan mengingat kejadian yang belakangan ini yang membuat saya begitu terbebani, dan memikirkan bagaimana tahap penyelesaiannya"

"setelah saya mewarnai, saya menjadi lebih bahagia meilhat warna-warna pada pola yang saya warnai"

Pada hari terakhir sesi, mahasiswa kembali diberikan lembar posttest untuk mengukur kembali tingkat kecemasan mengerjakan skripsi setelah diberi perlakuan. Instrumen yang digunakan untuk mengukur tingkat kecemasan adalah skala DASS-A yang digunakan sejak pretest hingga follow up.

Berdasarkan hasil analisis deskripsi dalam data posttest penelitian yang diperoleh dari respon delapan partisipan penelitian menunjukkan bahwa seluruh partisipan mengalami penurunan tingkat kecemasan mengerjakan skripsi. Pada posttest dan follow up kecemasan mengerjakan skripsi, seluruh partisipan mengalami penurunan tingkat kecemasan mengerjakan skripsi. Data menunjukkan bahwa 1 partisipan (12,5\%) tergolong rendah, 6 partisipan (75\%) terkategori sedang, dan 1 partisipan (12,5\%) terkagegori tinggi.

Tuntutan yang diperoleh mahasiswa semester akhir yang sedang memprogram skripsi yaitu beban berat untuk menyelesaikan tantangan dengan baik. Fikry \& Khairani (2017) mengemukakan bahwa kecemasan mengerjakan skripsi merupakan reaksi emosi individu karena proses pengerjaan skripsi yang menemukan rintanganseperti sulit menemukan judul skripsi, kesulitan mencari bahan bacaan, dan takut menemui dosen pembimbing. Hal ini sejalan denganhasil penelitian, diketahui mahasiswa mengalami rintangan seperti kesulitan menemukan literatur.

Mahasiswa yang sedang mengerjakan skripsi dan tidak lagi dapat menyeimbangkan antara tekanan yang diperoleh dengan tindakan yang sesuai mengakibatkan proses pengerjaan skripsi terhambat. Situmorang (2017) mengemukakan bahwa kecemasan mengerjakan skripsi merupakan reaksi individu karena memikirkan sesuatu yang buruk dapat terjadi selama proses pengerjaan skripsi. Individu berpikir bahwa pengerjaan skripsi akan menyita waktu dan pikiran.

Hasil uji hipotesis penelitian mengenai peranan metode mewarnai mandala terhadap kecemasan mengerjakan skripsi pada mahasiswa FPSI UNM dengan menggunakan uji Friedman menunjukkan nilai signifikansi sebesar $\mathrm{p}=0,01$ yang menunjukkan bahwa mewarnai mandala berperan untuk menurunkan kecemasan mengerjakan skripsi mahasiswa FPSI UNM yang sedang mengerjakan skripsi. Setelah pemberian perlakuan berupa mewarnai mandala, seluruh partisipan merasa tenang, senang dan rileks. Hal ini sejalan dengan kesan yang diberikan partisipan.

"saya merasa senang mewarnainya, setelah selesai saya merasa lega. Penatku sepertinya ikut pergi setelah mewarnai, menjadi lega" 
Selain itu, aktivitas mewarnai mandala membuat partisipan meningkatkan fokus. Hal ini sejalan dengan pernyataan Curry \& Kasser (2005) mengemukakan bahwa aktivitas mewarnai bentuk simetris, pola dan kompleksitas mandala membantu menciptakan fokus dan membawa pada keadaan relaksasi. Mandala dapat menurunkan kecemasan karena menggabungkan dua unsur yaitu terapi seni yang ditunjukkan dari bentuk seni dan meditasi dengan konsentrasipada pengalaman yang menyenangkan. Hal ini sejalan dengan kesan yang diberikan partisipan.

"setelah saya mewarnai, saya menjadi lebih bahagia meilhat warna-warna pada pola yang saya warnai"

"setelah mewarnai terasa lebih ringan, rileks dan fokus. Saya mengingat jika dulu saya orang yang fokus dan tekun. Sekarang senang dan bahagia karena mengingat bahwa saya dulu orang yang positif, sekarang saya lebih siap untuk meakukan yang terbaik."

Partisipan juga dapat mengekspresikan emosi sehingga partisipan merasa lega dan meningkatkan kesadaran diri untuk dapat menjalankan aktivitas lebih efektif daripada sebelum mewarnai mandala. Individu dapat mengekspresikan diri secara simbolis dan menemukan ketenangan pikiran melalui aktivitas mewarnai mandala, sebab mandala dapat memfasilitasi individuasi, proses integritas psikis, dan keutuhan diri. Teknik individuasi dari mandala memungkinkan individu untuk menumbuhkan kesadaran dan pemahaman akan diri secara keseluruhan hingga memberikan efek yang positif bagi kesehatan mental (Anderson, 2017). Hal ini sejalan dengan kesan yang diberikan partisipan.

"saya merasa seperti plong/lega, dan saat mewarnai mandala saya merasa berbicara sendiri dengan diri saya dan mengingat kejadian yang belakangan ini yang membuat saya begitu terbebani, dan memikirkan bagaimana tahap penyelesaiannya"

Berdasarkan pembahasan diatas, maka metode mewarnai mandala dapat mengurangi kecemasan mengerjakan skripsi. Kecemasan mengerjakan skripsi dapat dapat menurun dengan cara berkonsentrasi pada pengalaman yang menyenangkan ketika sedang mewarnai pola mandala.

Peneliti melakukan perbandingan antara pengukuran pertama yaitu pretest $\left(\mathrm{O}_{1}\right)$ dan pengukuran kedua yaitu posttest $\left(\mathrm{O}_{2}\right)$. Pengukuran ini dilakukan dengan menggunakan uji Wilcoxon signed ranks test dengan bantuan IBM SPSS Statistics 22, menunjukkan hasil nilai signifikansi sebesar $p=0,012$, yang berarti terjadi perubahan yang signifikan. Perubahan yang terjadi yaitu penurunan tingkat kecemasan mengerjakan skripsi pada partisipan dari tinggi ke sedang dan rendah.

Hasil dari perbandingan antara pengukuran pertama yaitu pretest $\left(\mathrm{O}_{1}\right)$ dan pengukuran ketiga yaitu follow up $\left(\mathrm{O}_{3}\right)$. Pengukuran ini dilakukan dengan menggunakan uji Wilcoxon signed ranks test dengan bantuan IBM SPSS Statistics 22, menunjukkan hasil nilai signifikansi sebesar $p=0,012$, yang berarti satu pekan setelah diberi perlakuan, terjadi perubahan yang signifikan pada partisipan penelitian. Perubahan yang terjadi yaitu penurunan tingkat kecemasan mengerjakan skripsi pada partisipan dari tinggi ke sedang dan rendah.

Hasil dari perbandingan antara pengukuran pertama yaitu posttest $\left(\mathrm{O}_{2}\right)$ dan pengukuran ketiga yaitu follow up $\left(\mathrm{O}_{3}\right)$. Pengukuran ini dilakukan dengan menggunakan uji Wilcoxon signed ranks test dengan bantuan IBM SPSS Statistics 22. Hasil menunjukkan nilai signifikansi sebesar $\mathrm{p}=0,343$, yang berarti sesaatdan satu pekan setelah diberi perlakuan, tidak terjadi perubahan yang signifikan pada partisipan penelitian.

Berdasarkan hasil observasi pada hari pertama penelitian nampak pada kecemasan berupa bibir terlihat kering, tangan bergetar, mengepal, menyentuh leher atau wajah. Partisipan juga menunjukkan tanda cemas seperti menekan rahang, duduk tidak tegap, tangan menyentuh masing-masing siku atau area perut. Pada hari terakhir penelitian frekuensi yang tunjukkan dalam tanda kecemasan lebih berkurang dari pada ketika awal penelitian. Ini menunjukkan bahwa terjadi penurunan kecemasan yang dialami oleh mahasiswa. Kecemasan yang dialami menurun setelah mendapatkkan efek dari pola dan warna dalam metode mewarnai mandala. Babin (2013) mengemukakan bahwa warna dapat digunakan sebagai salah satu teknik yang dapat mengatasi keluhan fisik dan emosi. 
Mahasiswa yang cemas berada pada keadaan tidak tenang dan membutuhkan keadaan relaksasi. Warna memiliki peranan dan pengaruh penting sebagai penghidup jiwa. Babin (2013) mengemukakan bahwa individu akan mengalami perubahan fisiologis ketika terpapar oleh warna tertentu. Warna dapat merangsang, membangkitkan, menekan, menenangkan, dan menciptakan perasaan hangat atau dingin.

Metode pewarnaan untuk menurunkan kecemasan akan lebih efektif ketika dibandingkan dengan media terstruktur. Harms (2011) mengemukakan bahwa mewarnai mandala adalah aktivitas memberi warna tertentu pada pola khas berbentuk garis dan lingkaran yaitu pola geometri. Mandala memiliki makna yang luas dan bentuk geometri memiliki makna psikologi yang tersirat. Geometri memiliki empat bagian dasar. Atas sebagai bagian kesadaran, bawah sebagai bagian ketidaksadaran, kiri merupakan bagian persepsi, dan sisi kanan adalah bagian apersepsi. Geometric pada mandala menjadi komunikasi simbolik untuk diri, memliki makna yang mempengaruhi diri dari waktu kewaktu. Ketika individu menghadapi bentuk geometric mandala, bentuk geometri akan dipersepsikan sebagai bentuk alam. Bentuk geometric tidak hanya menjadi sumber kreatifitas tetap juga mencerminkan keadaan psikologis batin. Aktivitas mewarnai geometric mandala dengan garis lengkung dan horizontal yangmelewati titik di tengah merupakan representasi diri, menghadirkan diri, membantu memusatkan perhatian kepada diri. Representasi dari diri yaitu bagaimana individu memandang dunia dan persepsi tentang diri individu dalamnya (Anderson, 2017).

Curry \& Kasser (2005) mengemukakan bahwa ide dasar dari terapi pewarnaan terletak pada emosi. Individu yang melakukan aktivitas mewarnai pada media berbentuk geometris yang kompleks, secara tidak langsung akan melibatkan perasaan batin yang mendalam. Individu yang melakukan aktivitas batin tersebut akan berguna untuk menghilangkan pikiran dan emosi negatif yang sering kali mendominasi kehidupan.

Media yang digunakan untuk mewarnai adalah empat macam pola mandala yang dikelilingi oleh bentuk lingkaran. Moss (2007) mengemukakan bahwa mandala adalah lingkaran dengan empat arah utama yang memiliki titik fokus utama. Bentuk lingkaran mandala mewakili bentuk seni yang menggambarkan totalitas diri. Mandala memiliki pusat utama yang dapat ditampilkan dalam bentuk titik maupun bunga yang bermakna bahwa segala kekuatan yang berlawanan memiliki asal yang sama sehingga dapat atasi.

Penelitian ini menggunakan empat pola mandala sistematis yang dapat membawa pada keadaan meditasi seperti rasa tenang sehingga mampu menurunkan kecemasan. Pisarik \& Larson (2011) mengemukakan bahwa Jung memandang mandala sebagai desain artistik yang dibuat dalam bentuk lingkaran yang mewakili makna diri. Henderson, Rosen, \& Mascaro (2007) mengemukakan bahwa mandala memiliki struktur desain melingkar yang terdiri dari bentuk simetris yang secara teratur digunakan untuk tujuan meditasi.

Terdapat enam warna yang disediakan dalam penelitian ini, yaitu merah, kuning, hijau, biru, ungu, dan jingga. Dari enam warna yang disediakan, partisipan dominan menggunakan warna biru dan hijau. Fincher (2000) mengemukakan bahwa warna dalam mandala memiliki makna tersendiri, yaitu (1) warna hijau merupakan warna alam, keseimbangan, dan harmoni yang memberi kesan kesegaran, kesehatan, kedamaian, dankemakmuran, (2) warna jingga merupakan warna yangmewakili sifat bersahaja yang memberi kesan daya tahan, kekuatan, dan ambisi yang baik, (3) warna ungu berhubungan dengan bangsawan, kehalusan, dan kekuasaan. Warna ungu menandakan kesabaran, kepercayaan, dan iman, (4) warna merah memberi energi dan menstimulasi tubuh. Warna merah meningkatkan kewaspadaan dan membawa kesadaran akan saat ini. Warna merah menandakan gairah, kehidupan, seksualitas, cinta, dan kekuatan yang diciptakan. Merah melambangkan darah, kemarahan, kekerasan, dan api, (5) warna biru merupakan warna langit yang cerah yang menunjukkan ruang tanpa batas, langit, dan keabadian. Warna biru dapat memberi efek yang menenangkan, (6) warna kuning melambangkan matahari dan ritme waktu yang digerakkan oleh terbitnya matahari. Warna kuning berkaitan dengan aspek energi dari prinsip maskulin. Kuning menandakan tingkat kesadaran yang tinggi, dan kelahiran.

Partisipan kembali memikirkan masalah yang dihadapi dan menemukan semangat baru ketika sedang mewarnai mandala. Partisipa juga merasa lega karena dapat mengekspresikan diri dan mengeluarkan emosi negatif menggunakan warna pada mandala. Partisipan merasa bahagia dan lebih tenang setelah mewarnai mandala. Anderson (2017) mengemukakan bahwa individu dapat mengekspresikan diri secara simbolis dan menemukan ketenangan pikiran melalui aktivitas mewarnai mandala. Mandala sebagai metode untuk memfasilitasi individuasi, proses integritas psikis, dan keutuhan diri. Teknik individuasi memungkinkan individu untuk menumbuhkan kesadaran dan pemahaman akan diri secara keseluruhan hingga memberikan efek yang positif bagi kesehatan mental. 
Mewarnai mandala dapat membantu menumbuhan kesadaran utuh sehingga memberi efek meditasi. Maka dapat disimpulkan bahwa mewarnai mandala berperan dalam menurunkan kecemasan mengerjakan skripsi pada mahasiswa FPSI UNM yang sedang mengerjakan skripsi.

\section{SIMPULAN}

Hasil uji hipotesis menunjukkan bahwa metode mewarnai mandala berperan untuk menurunkan kecemasan mengerjakan skripsi pada mahasiswa FPSI UNM yang sedang mengerjakan skripsi. Terdapat penurunan kecemasan mengerjakan skripsi pada mahasiswa sebelum diberi perlakuan (pretest), setelah diberi perlakuan (posttest). Penurunan kecemasan mengerjakan skripsi masih bertahan hingga satu pekan setelah diberi perlakuan (follow up).

Saran bagi peneliti berikutnya adalah menambah jumlah partisipan dalam penelitian sehingga hasil penelitian yang diperoleh dapat digeneralisasikan dan perlu menggunakan kelompok kontrol dalam penelitian. Faktor lain yang perlu dikontrol adalah berapa lama mahasiswa melakukan proses pengerjaan skripsi, sebab perbedaan waktu tersebut dapat mempengaruhi tingkat kecemasan.

\section{DAFTAR PUSTAKA}

Amaliyah, K. A., \& Palia, S. (2015). Efektivitas rational emotive behavioral trainingterhadap penurunan kecemasan menyusun skripsi mahasiswa. Jurnal Intervensi Psikologi, 7(2), 143-157.

Anderson, K. (2017). Effects of coloring mandalas on state-anxiety reduction with a focus on big-five personality traits. New London: Connectiant College.

Asmawan, M. C. (2016). Analisis kesulitan mahasiswa menyelesaikan skripsi. Jurnal Pendidikan Ilmu Sosial, 26(2), 51-57.

Azwar, S. (2016). Penyusunan skala psikologi. Yogyakarta: Pustaka Pelajar.

Babin, S. E. (2013). Color theory: The effects of color in medical environments. Honors College of The University of Southern Mississippi.

Carsley, D., Heath, N. L., \& Fajnerova, S. (2015). Effectiveness of a classroom mindfulness coloring activity for test anxiety in children. Journal of Applied School Psychology, 31, 239-255.

Curry, N. A., \& Kasser, T. (2005). Can mandallas reduce anxiety?. Journal of The American Art Theraphy Assocation, 22, 81-85.

Deasyanti \& Nuruzdah, M. (2017). Orientasi tujuan menyusun skripsi dan kecemasan dalam menulis skripsi. Jurnal Ilmu Penelitian dan Pengukuran Psikologi, 6(2), 102-105.

Fikry, T. R., \& Khairani, M. (2017). Kecerdasan emosional dan kecemasan mahasiswa bimbingan skripsi di Universitas Syiah Kuala. Jurnal Konseling Andi Matappa, 1(2), 108-115.

Fincher, S. F. (2000). Coloring mandalas: For insigh, healing, and self-expression. Boston: Shambala Publication.

Harini, N. (2013). Terapi warna untuk mengurangi kecemasan. Jurnal Ilmiah Psikologi Terapan, 1(2), 291-303.

Harms, D. (2011) Geometry of the mandala. Jung Journal: Culture \& Psyche, 5(2), 84-101.

Henderson, P., Rosen, D., \& Mascaro, N. (2007). Empirical study on the healing nature of mandalas. Psychology of Aesthetics, Creativity, and The Arts, 1(3), 148-154.

KBBI. (2018). Kamus besar bahasa indonesia (KBBI). Retrieved October 3, 2018, from https://kbbi.web.id/skripsi

James, R. (2015). Adullt coloring book: De-stress, relax \& let go with mandala meditation patterns (Vol. 2). Pennsylvania: Morgan Publishing.

Listanto, V., \& Demak, I. P. K. (2015). Kecemasan pada mahasiswa angkatan 2010 yang mengerjakan tugas akhir program studi pendidikan dokter FKIK UNTAD tahun 2010. Jurnal Ilmiah Kedokteran, 2(1), 40-49. 
Lovibond, P. F., \& Lovibond, S. H. (1995). The structure of negative emotional states: Comparison of the depression anxiety stress scales (dass) with the beck depression and anxiety inventories. Journal Behavior Research Theory, 33(3), 335-343.

Moss, R. (2007). The mandala of being: Discovering the power of awareness. Novato: New World Library. Pisarik, C. T., \& Larson, K. R. (2011). Facilitating college students' authenticity and psychological wellbeing through the use of mandalas: An empirical study. Journal of Humanistic Counseling, 50(1), 8498.

Seniati, L., Yulianto, A., \& Setiadi, B. N. (2011). Psikologi eksperimen. Jakarta: Indeks

Situmorang, D. D. B. (2017). Efektivitas pemberian layanan intervensi music therapy untuk mereduksi academic anxietymahasiswa terhadap skripsi. Jurnal Bimbingan Konseling Indonesia, 2(1), 4-8.

Situmorang, D. D. B., Mulawarman, Wibowo, M. E. (2018). Perbandingan efektivitas konseling kelompok CBT dengan passive vs active music therapy untuk mereduksi academic anxiety. Jurnal Psikologi Sains dan Profesi, 1(2), 143-152.

Vennet, R. V. D., \& Serice, S. (2012). Can coloring mandalas reduce anxiety? A replication study art therapy. Journal of The American Art Therapy Association, 29(2), 87-92.

Videbeck, S. L. (2011). Psychiatric-mental health nursing $\left(5^{\text {th }}\right.$ ed.). Netherlands: Wolters Kluwer 